\title{
ARTICLES
}

\section{Personhood and legal status: reflections on the democratic rights of corporations ${ }^{*}$}

\author{
Ludvig Beckman
}

\section{Introduction}

Corporations are regularly ascribed rights and duties, yet few believe they should have the right to participate and to vote in democratic elections. The notion that a corporation should be able to vote is typically dismissed as 'preposterous' as it contradicts the principle 'integral to liberal democracy' that only human beings should vote. ${ }^{1}$ This reply warrants the further, normative, question why only human beings should be able to vote in a democracy. But reasons grounded in normative considerations about democracy are parasitic on assumptions regarding the nature of the entities that can have democratic rights. And these are conceptual questions. The present analysis focuses on the conceptual issue and asks if the nature of corporations disqualifies them from being included in the demos.

It might seem obvious that corporations are not qualified as bearers of democratic rights and that only human beings are the kind of entities to which such rights apply. After all, the literal meaning of 'democracy' is rule by the people and corporations are not people. This argument should be rejected from the outright, however. The fact that 'demo-cracy' derives from Greek for 'people' is telling about the original meaning of democracy but does not decide how to speak about democracy today. As Josiah Ober points out in his penetrating exploration of classical talk of democracy; 'we are not bound by any past convention, much less by the inventors' original definition: if we can devise a better meaning for a political term, it should be preferred.' ${ }^{2}$ In addition, the claim that only people can have democratic rights is mistaken on its own terms since such rights are frequently extended to organizations ruled by democratic principles whether or not their

* I am very grateful for comments on earlier versions of this paper from Andreas Föllesdal, Andreas Gottardis, Sune Laegaard, David Owen as well as of the anonymous reviewers of this journal.

1 Frank Hindriks, 'How Autonomous are Collective Agents? Corporate Rights and Normative Individualism,' Erkenntnis 79 (2014): 1565-85; Ronald Dworkin, 'The Decision That Threatens Democracy,' The New York Review of Books 57 (2010): 63-67. Interestingly, history gives examples of corporate voting in political elections. Universities were able to vote, by virtue of being corporate bodies, in the United Kingdom until 1948. In Sweden, business corporations were entitled to vote in local elections between 1861 and 1920. See Einar Mellquist, Rösträtt efter förtjänst? Riksdagsdebatten om den kommunala rösträtten i Sverige 1862-1900 (Uppsala: Almkvist och Wicksell, 1974).

2 Josiah Ober, 'The Original Meaning of Democracy: Capacity to Do Things, not Majority Rule,' Constellations 15 (2008): 3-9. 
members are human beings. We are thus familiar with the notion that democratic rights can apply to associations that are not individual persons (in for example unions, employers' associations, supra-national organizations).

A further reason why democratic rights might apply exclusively to human beings is that liberal democracies are founded on the notion of popular sovereignty, according to which 'the people' is the ultimate source of public power. ${ }^{3}$ The constitution of the United States is a case in point. Following the preamble, the authority of the institutions of public power derives from 'We the people. ${ }^{4}$ As affirmed in subsequent case law, the terms 'citizens,' 'persons,' 'inhabitants' or 'subjects' do not include corporations but only beings of flesh and blood. ${ }^{5}$ Corporations are not citizens, they are at best 'like' citizens as they lack the required 'legal and administrative status.'

It is unclear to what extent legal practice should guide judgments about the conceptual prerequisites for democratic participation, however. The past took for granted that women, workers and the uneducated did not qualify as members of the people. These widely held perceptions clearly were not themselves grounds for them; the existence of a practice is not a reason for accepting it.

A different approach is to ask if the nature of the corporation precludes it from being the bearer of rights to political participation, given generally accepted theories of democracy. Here, we depart from Robert Dahl's theory of the democratic process according to which participatory rights apply to 'every person subject to a

3 Denis Galligan, 'The Sovereignty Deficit of Modern Constitutions,' Oxford Journal of Legal Studies 33 (2013): 703-32.

4 Ilya Shapiro and Caitlyn McCarthy, 'So What if Corporations Aren't People?,' The John Marshall Law Review 44 (2011): 701-16. Interestingly, the recent judgment by the U.S. Supreme Court in the much debated Citizens United v. Federal Election Commission (130 S Ct. 876 [2010]) indirectly addresses the extent to which democratic rights extend to non-human entities. The Court affirmed that the nature of an entity is immaterial to the question whether the government is entitled to suppress speech protected by the First Amendment. In his dissenting opinion, Justice Stevens noted that it might be a problem for the majority view 'that corporations are not permitted to vote, given that voting is, among other things, a form of speech.' John Paul Stevens, 'Opinion of John Stevens, Supreme Court of the United States, Citizens United, Appellant v. Federal Election Commission, January 21 (2010). See further Amy Sepinwall, 'Citizens United and the Ineluctable Question of Corporate Citizenship,' Connecticut Law Review 44 (2012): 575-604.

5 Jonathan Marcantel, 'The Corporations as a Real Constitutional Person,' UC Davis Business Law Journal 11 (2010): 221-65.

6 Jeremy Moon, Andrew Crane and Dirk Matten, 'Can Corporations be Citizens? Corporate Citizenship as a Metaphor for Business Participation in Society,' Business Ethics Quarterly 15 (2011): 429-53, esp. 436. Not all firms are corporations. Following David Ciepley, 'Beyond Public and Private: Toward a Political Theory of the Corporation,' American Political Science Review 107 (2013): 139-58, the modern corporation is characterized by limited liability, asset lock-in and entity shielding, meaning that owners are protected from claims held against the corporation and that corporations are protected against claims held against their owners. The modern corporation became influential in the 19th century and replaced the model where business enterprises where mere partnerships and therefore aggregation of individuals. See Jeroen Veldman, 'Incorporating Embodiment,' in Institutions Inc., eds. Elke Weik and Peter Walgenbach (London: Palgrave, 2016), 126. 
government and its laws. ${ }^{7}$ This principle of democratic inclusion stipulates that entities can have democratic rights only if they are persons that are subject to the law. Following this view, corporations can be afforded democratic rights only if they are indeed persons that are subject to the law. ${ }^{8}$

It can be objected that Dahl applied the principle of inclusion only to human beings. This is revealed by him referring exclusively to categories of human beings in his work and by the fact that he argued that democratic rights apply exclusively to human beings because only they enjoy 'equal intrinsic worth.' ${ }^{9}$ But the scope of application of Dahl's principle of democratic inclusion is potentially broader than Dahl had normative reasons to accept. The category of entities to which the principle applies need not coincide with the category of entities to which Dahl applied it. Thus, we are justified in asking whether conditions for democratic inclusion specified by Dahl apply to corporations even though he denied that corporations should be included.

If the principle of inclusion applies to corporations, it follows that they satisfy the necessary conditions for democratic inclusion. But to meet the necessary conditions for democratic rights is not to meet the sufficient conditions to that effect. That is, it does not follow that corporations should be included in the demos even if it can be shown that the principle of inclusion applies to them. On the other hand, if the result is that the principle of inclusion does not apply to corporations, this is a decisive reason for not including them. Thus, the present paper investigates whether corporations could be enfranchised, not whether they should be enfranchised.

Below, we distinguish between four conceptions of the claim that democratic inclusion applies exclusively to entities that are persons and subject to the law. The first is that democratic inclusion applies to entities that are legal persons, as they are both 'persons' and subject to the law. The second conception holds that membership in the demos is premised on subjection to the law and personhood understood in terms of sentience or self-awareness. The third conception holds that membership in the demos is premised on subjection to the law and personhood understood as moral agency that is defined in terms of certain constitutive substances of agency. The fourth conception, finally, holds that democratic inclusion requires subjection to the law and personhood understood as moral agency

7 Ludvig Beckman, The Frontiers of Democracy: The Right to Vote and Its Limits (London: Palgrave, 2009); Robert Dahl, Democracy and Its Critics (New Haven: Yale University Press, 1989); Claudio Lopéz-Guerra, 'Should Expatriates Vote?,' The Journal of Political Philosophy 13 (2005): 216-34; Sarah Song, 'The Boundary Problem in Democratic Theory: Why the Demos Should Be Bounded by the State,' International Theory 4 (2010): 39-68.

8 The focus here is on the principled basis for excluding corporations from the demos, not practical objections against including them. For example, some argue that corporations should not be enfranchised because their number is potentially infinite, making it possible for them to outvote human beings. See Cathal O’Madagain, 'Group Agents: Persons, Mobs or Zombies?,' International Journal of Philosophical Studies 20 (2010): 271-87, esp. 279. Though these are relevant problems, they are presumably avoidable by the proper regulation of corporate voting rights.

9 Dahl, Democracy and its Critics, 85. 
that is defined in terms of performative attributes. The question asked is what these distinct understandings of the principle of democratic inclusion imply for the democratic status of corporations.

\section{The principle of democratic inclusion}

Estimating the status of corporations from the vantage point of the principle of democratic inclusion requires reflection on the status of this principle. The first thing to note is that the principle can be conceptualized differently and that the way it defines the conditions for inclusion has implications for the kind of entities that can be included in the demos. Consider for example the view that democratic inclusion applies only to entities that are 'subject to coercion. ${ }^{10}$ This condition is not applicable to all entities because not all entities can be coerced in the sense of having the capacity to respond to coercive threats. An entity that lacks the capacity to observe and react to the threats others communicate is not liable to coercion and is for that reason not a potential subject to coercion. Hence, the idea that membership in the demos should depend on subjection to coercion has implications for the kind of entities that could be included in the demos.

However, in the present context, the principle of democratic inclusion is theorized differently. As defined here, rights to political participation apply to persons that are subject to the law; a necessary condition for the inclusion of $\mathrm{A}$ in $\mathrm{X}$ is that $\mathrm{A}$ is a person that is subject to the laws of X. There are consequently two properties necessary for the ascription of democratic rights; personhood and subjection to law. These conditions come together if personhood is understood exclusively in legal terms. ${ }^{11}$ The principle of democratic inclusion then applies only to entities that are legal persons that are also subject to the law. This is a view that might generate support for the claim that democratic inclusion applies to corporations. If corporations were legal persons, they would be eligible for democratic rights to the extent that they are also legal subjects. ${ }^{12}$ Indeed, the legal philosopher Karl

10 Michael Blake, 'Immigration and Political Equality,' San Diego Law Review 45 (2008): 963-79.

11 Democratic theory proposes two radically different principles of democratic inclusion: the allaffected principle and the all-subjected principle. Both have been invoked in relation to the democratic rights of corporations. For the claim that corporations should be afforded democratic rights on the basis of the all-subjected principle, see John Hasnas, 'Should Corporations Have the Right to Vote?: A Paradox in the Theory of Corporate Moral Agency,' Journal of Business Ethics (2016), 1-14. https://doi.org/10.1007/s10551-016-3172-0. For the claim that corporations should be afforded democratic rights following the all-affected principle, see Steven Gerencser, 'The Corporate Person and Democratic Politics,' Political Research Quarterly 58 (2005): 625-35, esp. 629. In this paper, I focus exclusively on the all-subjected principle though I do not believe the conclusions depend on it.

12 Hasnas, 'Should Corporations Have the Right to Vote?'; Robert White, 'Corporations are People Too: An Argument for Corporate Moral Personhood,' The Journal of Ayn Rand Studies 14 (2014): 97-123, esp. 117. 
Olivecrona insisted that corporations, by virtue of being legal persons, ought to enjoy any legal right that does not presuppose bodily existence. ${ }^{13}$

Subjection to law and personhood should nevertheless be kept distinct as they serve distinct functions in the theory of democratic inclusion. There is a distinction between properties that are required to obtain in the relationship between the state and an entity, and properties that are required to obtain by the entity. ${ }^{14}$

The first defines relevant relational features that are necessary to 'trigger' democratic rights. According to the all-subjected principle, the relational features that obtain between the state and an entity are defined in terms of subjection to law. The second condition is concerned with the nature of entities and the kind of properties they need to possess to be members of the demos. Given that not all types of entities are qualified in the second sense, 'trigger' questions do not arise in relation to all kinds of entities.

A further consideration to bear in mind is that the principle of democratic inclusion is here understood to specify only the necessary, not the sufficient, conditions for democratic rights. The alternative understanding is that principles of democratic inclusion are all we need in order to allocate voting rights. This principalism is illustrated by John Hasnas's claim that corporations qualify as members of the demos following the principle of democratic inclusion. ${ }^{15}$ Against Hasnas it can be objected that democratic rights are moral rights and that moral rights apply only if they serve the critical and morally pertinent interests of relevant entities. Absent a compelling account of the critical and morally pertinent interests served by extending voting rights to corporations, the claim that they ought to be enfranchised does not carry moral weight. ${ }^{16}$

A further objection against the attempt to deduce normative conclusions from the principle of democratic inclusion is that it obscures the distinction between moral and democratic evaluation. Democracy is the idea of rule by the people. The realization of this idea is not necessarily morally compelling in every instance just because it is democratic. Normative questions should be kept distinct from questions regarding the meaning of democracy. Charles Beitz is making a similar point when he criticizes the use of various principles of inclusion in democratic argument. According to Beitz, the scope of participatory rights must be sensitive to the constitutional context as well as to the moral ends that democratic proce-

13 Karl Olivecrona, Studier över begreppet juridisk person i romersk och modern rätt (Uppsala: Särtryck av Uppsala Universitets Årsskrift, 1928), 7.

14 The relationship between the trigger question and the entity question runs in the other direction too. To claim that an entity can be a member of the demos only if it possesses certain attributes has repercussions for permissible answers to the trigger question. For example, the claim that only entities that are citizens can be members of the demos runs counter to the claim that demos membership is triggered by subjection to the law.

15 Hasnas, 'Should Corporations Have the Right to Vote?'.

16 Adina Preda, 'From Corporate Moral Agency to Corporate Moral Rights,' Law \& Ethics of Human Rights 11 (2017): 135-59, esp. 143. 
dures are designed to serve. ${ }^{17}$ The moral ends that justify democratic procedures are specified through an egalitarian justification of the institutions of social cooperation, or what is also known as the basic structure of society. The point is that the extent of democratic inclusion must be sensitive to these wider considerations and not only to the meaning of a specific principle of inclusion.

In the case of corporations, I shall take it that the condition for them being subject to the law is less controversial than the condition for them having the intrinsic properties that make them relevant objects of consideration from the perspective of democratic inclusion. It is in other words more controversial to what extent corporations are persons in the relevant sense than to what extent they are subject to the law.

\section{Corporations as legal persons}

The first condition for democratic inclusion, according to the theory accepted here, is subjection to law; $\mathrm{A}$ is a subject to the laws in legal system $\mathrm{X}$ if and only if some legal rule recognized as valid within $\mathrm{X}$ pertains to $\mathrm{A}$. An entity would consequently be counted as subject to the law in the relevant sense to the extent that some legal provision applies to it.

The conditions for democratic inclusion are extremely wide on this account. The law 'applies' to various entities that are inanimate objects, that cannot plausibly be considered as candidates for democratic inclusion. For instance, most legal systems include rules that refer to chemical compounds, forests and the air that we breathe. In the widest sense of the expression, 'the law' would thus seem to apply to these entities as they fall within the purview of the law.

In order to narrow down the category of legal subjects, a distinction is required between the subjects of law and the objects of law. Legal subjects are the bearers of legal rights and duties and, clearly, neither chemical compounds, nor trees or clouds, are bearers of legal rights or duties; chemical compounds are not legally obliged not to poison us, forests do not have legal duties to stand tall and the air is not required by law not to pollute. These entities do not have legal duties because they are mere objects of law, not legal subjects.

The distinction between the subjects of law and the objects of law can be explained by reference to the scope of legal norms. Not every legal rule implies a norm, as is exemplified by rules that provide definitions of objects or standards for their measurement. Legal rules that are norms are distinguished by the fact that they impose 'orders, permissions or authorizations' and apply only to enti- 
ties for which these normative relations are meaningful. ${ }^{18}$ The category of legal subjects is therefore identified as entities to which legal norms apply. ${ }^{19}$

These considerations allow us to extract a revised understanding of the claim that democratic inclusion requires subjection to the law: the inclusion of $\mathrm{A}$ in the legal system $\mathrm{X}$ is conditioned by $\mathrm{X}$ ascribing legal rights or duties to $\mathrm{A}$. The relevant subjects, so conceived, are akin to legal persons. The legal person is defined by the capacity to hold legal rights or duties and by the ability and power to initiate legal action against others. ${ }^{20}$

Following this view, the dual conditions of legal subjection and personhood coincide. In so far as an entity is recognized as a legal person within a legal system, it follows that it is also a legal subject of that system. In order to determine the range of application of the democratic principle of inclusion it is consequently sufficient to distinguish between entities that are recognized as legal persons and entities that are not. To be a legal subject is the mark of a legal person and - in a democracy - only legal persons are candidates for voting rights.

Now, corporations are regularly understood as legal persons. They are legal persons in the dual sense of being empowered by the law to initiate legal action and being the bearers of legal rights and duties. A stark illustration of the extent to which corporations are in fact the bearers of legal rights is that almost every right enumerated by the Bill of Rights of the U.S. Constitution are enjoyed by corporations. ${ }^{21}$ Corporations are also recognized by international law as legal persons as they are ascribed numerous legal rights and duties. The European Convention of Human Rights is most explicit in this regard, as it extends protections to 'any person, nongovernmental organization or group of individuals.'22

It might be objected that recognition of the corporation as a legal person is a descriptive, not a normative claim. The fact that corporations are construed as legal persons in most legal systems does not necessarily entail that they ought to

18 Benjamin Spagnolo, The Continuity of Legal Systems in Theory and Practice (Oxford: Hart, 2015), 45; Joseph Raz, The Concept of a Legal System (Oxford: Clarendon, 1970), 170.

19 It follows that the category of legal subjects cannot be defined by the law since legal definitions are not legal norms and only legal norms can identify the extent to which entities are subject to normative relations. Hence, the legal claim ' $\mathrm{A}$ is a legal subject' does not itself justify the conclusion that $\mathrm{A}$ is a legal subject because this claim does not represent a legal norm and therefore does not define the legal relations applicable to A. Jan Klabbers, 'Legal Personality: The Concept of Legal Personality,' Ius Gentium 11 (2005): 35-66, esp. 46.

20 Lawrence Solum, 'Legal Personhood for Artificial Intelligences,' North Carolina Law Review 70 (1992): 1231-87, esp. 1239. The condition that legal persons should be able to take legal actions is contested as it appears to deny legal personality to minors, disabled and others lacking such capacity. See Richard Tur, 'The "Person" in Law,' in Persons and Personality. A contemporary Inquiry, eds. Arthur Peacocke and Andrew Giller (Oxford: Basil Blackwell, 1986).

21 The sole exception is reportedly the constitutional right against self-incrimination that is not recognized for corporations. Note, 'Constitutional Rights of the Corporate Person,' Yale Law Journal 91 (1982): 1641-58, esp. 1652.

22 Cristina Lafonte, 'Should We Take the "Human" out of Human Rights? Human Dignity in a Corporate World,' Ethics and International Affairs 30 (2016): 233-52, esp. 241. 
be so construed. Following one view, legal personality is premised on the possession of the attributes of a moral person. The idea is that only entities that have the interests and capacities required by them to be moral persons should be recognized as persons in the eyes of the law. The implication is that some entities are not eligible for legal personality because of their intrinsic properties. I shall take this position to mean that there are legal subjects that should not be regarded as legal persons unless they exhibit the properties that make them persons in a non-legal sense. The conditions for non-legal personhood are examined in the sections to follow.

However, the predominant view is that the status of legal personality is a mere 'artifice' in the sense that it does not depend on prior demonstration that the entity possesses any intrinsic properties. ${ }^{23}$ Rather, the legal person is a 'fiction' employed for the purpose of illustration and simplification and not for the purpose of identifying features that are intrinsic to natural objects. ${ }^{24}$ The implication is that the status of legal personality is not the privilege of just some kinds of entities. Legal personality is a status available to anybody, or anything, whenever the law so declares. ${ }^{25}$ According to this view, legal practice ought to guide our normative judgments about the constitutive elements of legal personality.

In practice, the artifice conception of legal personality is consistent with refusing to extend legal personality to particular objects for reasons of legal expediency. For example, though a case can be made in favor of extending legal personality to non-biological machines no legal system has so far been willing to accept it. ${ }^{26}$

The conclusion then is that nothing in the concept of legal personality precludes corporations from being legal persons. Moreover, if recognition as a legal person by a legal system implies legal subjection, it follows that corporations thereby meet both of the necessary conditions defined by the principle of inclusion. The 'artifice' theory of legal personality thus furnishes the conceptual resources for the conclusion that corporations comply with the all-subjected principle of democratic inclusion. Legal systems that recognize corporations as legal persons are, perhaps unintentionally, committed to accept that corporations satisfy the necessary conditions for democratic inclusion.

23 Ngaire Naffine, 'Liberating the Legal Person,' Canadian Journal of Law and Society 26 (2011): 193-203.

24 Hans Kelsen, 'On the Theory of Juridic Fictions. With Special Consideration of Vaihinger's Philosophy of the As-If,' in Legal Fictions in Theory and Practice, Law and Philosophy Library 110, eds. Maksymilian Del Mar and William Twining (Berlin: Springer, 2015 [1919]), 7.

25 See Tur, 'The "Person” in Law,' 121; Jessica Berg, 'Of Elephants and Embryos: A Proposed Framework for Legal Personhood,' Hastings Law Journal 59 (2007): 369-406, esp. 380, and Ngaire Naffine, 'From Cheshire Cats to Responsible Subjects,' The Modern Law Review 66 (2003): 346-67. 


\section{Objections to legal personality as necessary condition}

Now, it may be held that corporations and human beings differ in the extent to which they are persons in the eyes of the law. As noted by Richard Tur, legal personhood can be considered a continuous property that is possessed by an entity in various degrees. ${ }^{27}$ So, although it is normally recognized that both infants and adults are legal persons, it is also true that adults are usually regarded as legal persons to a greater extent than infants. Given that legal personality comes in degrees, it is a small step to argue that this should be reflected in the necessary conditions for democratic inclusion. The principle of democratic inclusion should therefore be understood to apply only to entities that exhibit sufficient legal personality. ${ }^{28}$ Understood in this revised sense, it is possible to deny that the principle of democratic inclusion applies to corporations even though they are legal persons. The claim would be that corporations are legal persons only in a reduced sense and therefore do not sufficiently exhibit legal personality as to meet the necessary conditions for democratic inclusion.

Yet, the question is whether the categorical insistence on the full status of legal personality is plausible, as required by the revised principle of democratic inclusion. The distinction between full and reduced legal personality is making sense in the case of children because of implicit but crucial background conditions. Children and infants are not afforded legal personality in the full sense because they are not fully rational and competent. So, the reason why the reduced legal status of children matters to democratic inclusion is also the reason why they have reduced legal status in the first place. The result is that full legal personality is a conditional, not a categorical, requirement; it is conditional on the reasons for reduced legal status being the same as the reasons for reduced democratic status.

The implication is that it matters not just if corporations are not legal persons to the same extent as adult human beings but also why they are not legal persons to that extent. Now, the reduced legal status of children and other categories of disenfranchised human beings (non-citizens, mentally disabled) is typically motivated either by them being insufficiently competent or by them not belonging to the relevant domain. ${ }^{29}$ Do the same considerations apply to corporations? That does not appear to be the case. Corporations are competent in the sense of possessing the capacities to gather and process relevant information and to participate in decision-making procedures. Other dimensions of competence might of course be relevant and there is more to be said about the democratic legitimacy of restrictions that are based on competence. Yet, it is not the case that corporations fail conspicuously to satisfy this condition. Also, corporations belong to the territory of the state (though it is sometimes unclear which) as determined on the basis of its place of incorporation, the location of the headquarters or the nation- 
ality of its owners. ${ }^{30}$ Based on these considerations, it follows that even if accepted that corporations are legal persons only in reduced sense, it is not clear that this reduced status is motivated by considerations that justify exclusion from democracy.

A different objection against legal personality as necessary for democratic inclusion is that it runs counter to the inclusive aspirations of the democratic ideal. Steven Gerencser argues that past exclusions from suffrage were justified by the practice of denying legal standing to minorities and others of perceived inferior status. ${ }^{31}$ The idea that democratic inclusion applies only to entities recognized as legal persons risk condoning the history of exclusion as it offers a rationale for why people without legal status should be denied also democratic rights.

The truth of the empirical premise for this objection is debatable, however. Arguably, legal personality has rarely if ever been denied to marginalized groups in society. Even in antebellum American South, where the entire legal and political system was designed to keep in place slavery in its most brutal form, pockets in law remained where the black person was treated as a subject and not as a mere object of law. The legal status of slaves in the Southern states remained ambiguous as the slave was depicted by courts as 'property but also as persons. ${ }^{32}$ The evil of slavery did not depend on denial of legal personality but on refusal to acknowledge equal and fundamental rights.

On a more positive note, we should not forget that legal status is fundamentally important to human beings. The significance of legal status is reflected in the 'human right to legal personality' and the fact that it is found highest up on the list of the rights enumerated in the Universal Declaration of Human Rights. ${ }^{33}$ The claim that democratic inclusion is conditioned by legal status is consequently tantamount to the claim that democratic rights depend on a status of universally recognized significance. Rather than being the basis for exclusion, legal personality provides grounds for inclusion.

Though the priority of legal status to democratic rights is not as such a reason for denying corporations democratic rights, it does offer grounds for refusing democratic rights to other entities that presently lack legal status. Non-human animals are a case in point, as they remain objects of law. There is no prospect for the Unternehmensgeschichte / Journal of Business History 51 (2006): 149-65, esp. 152. Interestingly, the majority in Citizens United conceded that one permissible ground for restricting the democratic rights of (some) corporations is control by foreign interests. See Dworkin, 'The Decision That Threatens Democracy.'

31 Gerencser, 'The Corporate Person and Democratic Politics.'

32 Arnold Sio, 'Interpretations of Slavery: The Slave Status in the Americas,' Comparative Studies in Society and History 7 (1965): 289-308.

33 Lisette ten Haaf, 'Future Persons and Legal Persons: The Problematic Representation of the Future Child in the Regulation of Reproduction,' Laws 5 (2016): 10. 
extension of democracy to entities that are not recognized as legal persons. ${ }^{34}$ The implication is that non-human animals do not meet the necessary conditions for democratic inclusion until their legal status has undergone a radical transformation.

\section{Corporations as natural persons}

Whereas legal personality is pragmatically decided by the law, the extent to which an entity should be regarded as a person is not a legal question. An entity with the characteristics of a natural person remains a person whatever the law says. Hence, the concept of the person is not equivalent to the concept of the legal person; there can be persons not recognized as legal persons just as there can be legal persons that are not persons.

Given these distinctions, the principle of democratic inclusion could be understood to require the possession of personhood as well as legal personality. The claim would be that the demos should include only entities subject to legal norms that are also natural persons. The consequent principle of democratic inclusion is that the inclusion of $\mathrm{A}$ in the legal system $\mathrm{X}$ is premised on $\mathrm{A}$ being a legal subject and a person.

Now, everyday language knows of many ways of speaking about corporations as if they were persons. Traits unique to persons are regularly ascribed to corporations, as when they are said to be responsible for what they do, or as when corporations are depicted as good, smart, bad or stupid. Corporations are frequently held to account for polluting the environment, for not providing decent working conditions, for engaging in bogus transactions with criminal organizations, and so on. Corporations are in short treated as if they were moral persons. Yet, from the fact that corporations are spoken of as if they were persons, it clearly does not follow that they are persons. Often, when corporations are held to account, the target is really some decision or policy that is attributable to individual members of the corporation rather than to the corporation as a group agent. ${ }^{35}$

In order to investigate whether corporations are, or can be, moral persons we should rather begin by identifying the defining attributes of the person. The sense in which an entity is a person is often understood either in Lockean terms, as the capacity for self-consciousness, or in Kantian terms, as grounded in cognition. ${ }^{36}$ However, other qualities are intermittently cited as essential to person-

34 Daniel Thym, 'Ambiguities of Personhood, Citizenship, Migration and Fundamental Rights in EU Law,' in Constructing the Person. Rights, Roles, Identities in EU Law, eds. Loïc Azoulai, Ségolène Barbou des Places and Etienne Pataut (London: Hart, 2016).

35 Stephen Wilks, The Political Power of the Business Corporation (Cheltenham: Edward Elgar, 2013), 22.

36 Ainsley Newson, 'Personhood and Moral Status,' in Principles of Health Care Ethics, eds. Richard E. Ashcroft et al., second edition (Chichester: John Wiley \& Sons, 2007), 277; Jenny Teichman, 'The Definition of Person,' Philosophy 60 (1985): 175-85, esp. 181. 
hood. In a survey of the literature, Tom Beauchamp identifies as potential conditions for personhood the capacity for intentionality, free will, language acquisition, pain reception and emotions. ${ }^{37}$ Despite the differences, these concepts have in common that personhood depends on mental processes. The distinction between persons and non-persons therefore does not depend on the physical features of an entity; personhood is psychological, not biological. ${ }^{38}$

Though personhood is a function of psychological properties, the consequences of attributing personhood are ineluctably normative. ${ }^{39}$ The normative aspect of personhood is discernable in claims to the effect that a person is owed respect in ways that a non-person is not. The respect owed to persons offers a potential explanation for the claim that personhood is a precondition for democratic inclusion. If persons are by definition entitled to respect, it might be held that people that are subjected to binding norms are respected only if they are granted opportunities to participate in the creation of these norms. The conceptual underpinnings of this normative account of personhood can be understood in broadly two distinct ways.

\section{Personhood as sentience}

One view is that personhood is a moral status that depends on the capacity for sentience, thought or self-awareness. This view corresponds to what Mary Ann Warren terms the 'minimalist' account as it sets a comparably low bar for personhood. ${ }^{40}$ These properties are present among a variety of human beings that are subject to legal norms and yet excluded from the demos. Infants, children and people with mental disabilities are persons, either because they hold the capacity for sentience or because they have the capacity for self-awareness. If personhood in any of these senses is among the preconditions for democratic inclusion, it follows that infants, children and the mentally disabled fall under the purview of this principle. The principle of democratic inclusion applies to any entity that is both a legal subject and a natural person, where the latter is defined in terms of sentience or self-awareness.

Some human beings that are subject to norms are not persons in the above sense, however. Consider the case of people in coma or anencephalic infants. Even though members of both categories are the beneficiaries of legal rights and in

37 Tom Beauchamp, 'The Failure of Theories of Personhood,' Kennedy Institute of Ethics Journal 9 (1999): 309-24.

38 Bert Gordijn, 'The Troublesome Concept of the Person,' Theoretical Medicine and Bioethics 20 (1999): 347-59; Mary Anne Warren, Moral Status: Obligations to Persons and Other Living Things (Oxford: Oxford University Press, 2000), 93.

39 Beauchamp, 'The Failure of Theories of Personhood'; Daniel Dennett, 'Conditions of Personhood,' in What Is a Person?, ed. Michael F. Goodman (Berlin: Springer Verlag, 1988), 193. 
that sense qualify as legal persons, they are neither self-aware nor sentient. ${ }^{41}$ More controversially, in some jurisdictions the fetus is recognized as a legal person in spite of the fetus not being a person on any of the criteria mentioned above. $^{42}$

Personhood in the minimalist sense is not necessarily the privilege of human beings, however. As frequently observed, the 'person' is a genus of which there can be many species. ${ }^{43}$ It appears likely that other hominid species, the Neanderthals or the Homo erectus, were also persons. It is also likely that certain species of non-human animals qualify as persons by virtue of being either sentient or self-aware. David DeGrazia argues that dolphins, chimpanzees, gorillas and orangutans are in the grey zone between clearly not persons and clearly persons. ${ }^{44}$ There is nothing about the insistence that personhood is a requirement for democratic inclusion that entails the exclusion of non-humans from the demos. Of course, legal personality is also a condition for democratic membership, following the principle of inclusion considered here. The point, however, is that a reason for the recognition of legal personality might be that the entity is already recognized as a natural person. As argued in a motion put before the Romanian parliament in 2014, dolphins should be accepted as legal persons because they exhibit 'developed intelligence [and] the capacity to form complex social relations. ${ }^{45}$ Once non-human animals are recognized as persons in both the legal and natural sense of term, the principle of democratic inclusion inevitably extends to them. The ensuing principle of democratic inclusion is the following: inclusion of $\mathrm{A}$ in legal system $\mathrm{X}$ is premised on $\mathrm{A}$ being subject to $\mathrm{X}$ as well as A being a natural person in the minimalist sense of the term.

Now, we already know that corporations can be legal persons. The question then is whether they can also be natural persons. An affirmative answer is bewildering if 'person' requires either sentience or self-awareness. So understood, personhood does not apply to collectives as they are neither sentient nor self-aware. ${ }^{46}$ Corpo-

41 Berg, 'Of Elephants and Embryos,' 379, argues that anencephalic infants are unique in being the bearers of legal rights and yet not being persons. By contrast, Dennett, 'Conditions of Personhood,' 175, suggests that 'infant human beings, mentally defective human beings, and human beings declared insane' are not persons while he presumably does not deny that they have rights. There will also be human beings that are excluded from democratic rights by virtue of being neither persons nor legal persons. The brain dead are a case in point. See Ten Haaf, 'Future Persons and Legal Persons,' 6.

42 Note, 'Constitutional Rights of the Corporate Person,' 1755.

43 Lynne Rudder Baker, Persons and Bodies: A Constitution view (Cambridge: Cambridge University Press, 2016), 92, and Newson, 'Personhood and Moral Status.'

44 David DeGrazia, 'On the Question of Personhood beyond Homo Sapiens,' in In Defense of Animals, ed. Peter Singer (Oxford: Blackwell, 2006), 44.

45 Geeta Shyam, 'The Legal Status of Animals. The World Rethinks its Position,' Alternative Law Journal 40 (2015): 266-70.

46 Hindricks, 'How Autonomous are Collective Agents?'; O’Madagain, 'Group Agents: Persons, Mobs or Zombies?'; and Ben Rich, 'Postmodern Personhood: A Matter of Consciousness,' Bioethics 11 (1997): 206-16. 
rations cannot feel and corporations cannot think; McDonalds is neither sad nor happy, IKEA does not reflect upon its own existence.

Justice Stevens, writing for the minority in Citizens United, defended the view that only persons with the capacity to feel or reflect should be regarded as potential members of the demos. According to Stevens, corporations are not included in 'We the people' because they have 'no consciousness, no beliefs, no feelings, no thoughts, no desires. ${ }^{47}$ The conclusion is that corporations should not have the right to vote if personhood is a necessary requirement for membership in the demos and if personhood is defined in terms of either sentience or self-awareness.

\section{Personhood as agency}

On a different reading, personhood is equivalent to moral agency. Given that the principle of democratic inclusion requires personhood and that personhood is defined in terms of moral agency, democratic rights apply only to moral agents. Mary Anne Warren terms this the 'maximalist' understanding as it raises the bar for any entity to qualify as a person. ${ }^{48}$ Democratic inclusion so defined, covers only entities that are both moral agents and legal persons.

The opposite of a moral agent is a moral patient. Though both agents and patients have moral status and can have moral rights, only agents are 'bound by' moral requirements. Ben Saunders argues that 'agents' but not 'patients' can be members of the demos. ${ }^{49}$ The reason why is presumably that only moral agents can be held morally accountable for failure to abide by legal duties. Alternatively, as John Hasnas argues, only agents have the ability to understand and to follow moral imperatives. ${ }^{50}$ Following Hasnas, corporations can be agents in this precise sense and should therefore be considered eligible for democratic rights.

The most influential account of corporations as moral agents is developed by Peter French. ${ }^{51}$ Following French, corporations are moral agents to the extent that they exhibit an 'internal decision structure' analogous to that by which human beings form intentions and make decisions. Corporations should be regarded as 'fully-fledged moral persons' that are capable of moral responsibility and to whom moral rights can be attributed. Indeed, French argues that groups that are moral persons 'will have whatever privileges, rights and duties as are, in the normal course of affairs, accorded to all members of the moral community. ${ }^{52}$ This seems an exaggeration though. Corporate moral agents presumably have neither rights to sexual integrity nor rights not to be enslaved, as it is unlikely that they have interests that justify the corresponding duties. ${ }^{53}$ But the extent of moral 
rights for corporate moral agents is not our concern. More relevant is the observation that corporations do seem to meet the 'person-condition' for democratic inclusion once it is understood in terms of moral agency.

French's understanding of group agency has been developed and revised by Christian List and Philip Pettit. Their view is that moral agency can justifiably be attributed to an entity either if it possesses the substances that are constitutive of agency, or if it performs like an agent. Christian List and Philip Pettit defend the latter approach and argue that moral agency involves 'not the presence of any non-material substance but the fact that the agent's material substance is organized in a manner that makes certain performances possible. ${ }^{54}$ The upshot is that we have reason to recognize an entity as a moral agent to the extent that it behaves as a moral agent. The decisive question then is whether corporations have the capacity to behave in ways that are typical of moral agents. If they do, we are entitled to conclude that they are moral agents. ${ }^{55}$

Though List and Pettit accept that corporations can be moral agents, they do not believe that corporations are therefore 'fully fledged persons.' Not all moral agents have the same moral standing and it makes perfect sense, they argue, to deny corporations equal moral rights on a par with human beings even if they are moral agents. The basis for this view is 'normative individualism'; in order for something to be good, it must be good for some human being. ${ }^{56}$ Pettit cautions against refusing to recognize corporations as moral agents simply because they are not human beings just as he cautions against recognizing corporations as moral equals simply because they are moral agents. ${ }^{57}$

The performative conception of moral agency provides a distinct understanding of the conditions for democratic inclusion. There is a distinction between the proposition that democratic inclusion is conditioned by the substances constitutive of moral agency and the proposition that democratic inclusion is conditioned by the capacity to behave as a moral agent. Whereas the former does not apply to corporations, as corporations lack 'moral-agency substance,' the latter does apply to corporations under certain conditions. The conclusion is that the principle of inclusion applies to corporations if personhood is understood as moral agency and if moral agency is understood in performative terms. The principle of inclusion does not apply to corporations, however, if personhood is understood in terms of the substances that are believed to constitute moral agency.

54 Christian List and Philip Pettit, Group Agency: The Possibility, Design, and Status of Corporate Agents (Oxford: Oxford University Press, 2011), 172.

55 Kenneth Goodpaster and John Matthews, 'Can a Corporation Have Conscience?,' Harvard Business Review 1 (1982): 132-41.

56 List and Pettit, Group Agency, 182.

57 Philip Pettit, 'Two Fallacies about Corporations,' in Performance and Progress: Essays on Capitalism, Business, and Society, ed. Subramanian Rangan (Oxford: Oxford University Press, 2015). 


\section{Conclusions}

The nature of the person in democratic decision-making is a neglected topic in democratic theory. Due to recent legal developments, the question is increasingly pertinent as it is clear that corporations are today considered eligible for an increasing array of legal rights that were previously regarded as the privilege of human beings.

This paper has not explored the democratic status of corporations in contemporary practices but has investigated the democratic status of corporations given what I take to be the standard conception of democratic inclusion. Following this principle, democratic rights extend only to entities that are persons as well as subjects of law. What this means is not entirely clear, though, as I argue that at least four distinct readings of these conditions can be distinguished. The principle of democratic inclusion consequently generates four distinct conceptions of the necessary conditions for democratic inclusion. The first is that only legal personality is required. The second is that democratic inclusion applies only to entities that are both legal persons and sentient or self-conscious persons. The third version of the principle is that democratic inclusion applies only to entities that are both legal persons and moral agents, where the latter involves the possession of the substances constitutive of moral agency. The fourth version of the principle is that democratic inclusion requires both legal personality and moral agency, where the latter depends on the ability to perform as a moral agent. The first and the fourth view is consistent with the inclusion of corporations in the demos, whereas the second and the third view is not.

In the end, the case of the right to vote of corporations offers lessons both for our understanding of the substance of principles of democratic inclusion and for the limited purchase of such principles. Though abstractly phrased principles should often guide our thinking about the scope of democratic rights, we risk getting it all wrong unless we also consider the moral values and ends from which these principles derive. 